\title{
NOTE
}

\section{AN ALTERNATIVE TO AFFIRMATIVE ACTION: ATTRIBUTING LACK OF DIVERSITY IN UNDERGRADUATE INSTITUTIONS TO A FAILING EDUCATION SYSTEM}

\author{
Michele Sherretta*
}

In the recent Supreme Court decision, Grutter v. Bollinger, ${ }^{1}$ the Court upheld the use of race-based affirmative action in admissions processes at higher education institutions. In the course of holding that diversity is a compelling interest, and that narrowly tailored race-conscious programs may be used to achieve diversity at graduate and undergraduate institutions, the Court also noted that such "race-conscious admissions policies must be limited in time."

It has been [twenty-five] years since Justice Powell first approved the use of race to further an interest in student body diversity in the context of public higher education [in Regents of University of California v. Bakke ${ }^{3}$. Since that time, the number of minority applicants with high grades and test scores has indeed increased. We expect that [twentyfive] years from now, the use of racial preferences will no longer be necessary to further the interest approved today. ${ }^{4}$

* Candidate for J.D. in 2004 from the University of Pittsburgh School of Law.

1. Grutter v. Bollinger, 123 S. Ct. 2325 (2003). See also Gratz v. Bollinger, 123 S. Ct. 2411 (2003). Grutter and Gratz both involved the constitutionality of the affirmative action policies in place at the University of Michigan. Gratz involved the policy applied at the undergraduate level, specifically the College of Literature, Science and the Arts, while Grutter involved the policy applied at the university's law school. Though the two schools' affirmative action policies were different, and the Court came to different results in each case, the rationale was the same in both and was set forth primarily in Grutter.

2. Grutter, 123 S. Ct. at 2346

3. Regents of the Univ. of Cal. v. Bakke, 438 U.S. 265 (1978).

4. Grutter, 123 S. Ct. at 2346-47 (citations omitted). 
In the wake of the decision approving the continued use of race-based affirmative action programs, many have questioned whether the Court has made the right decision. ${ }^{5}$ This Note asserts that rather than debating the effectiveness or appropriateness of affirmative action at the university level, the focus should be on reforming the entire education system from the ground up in order to achieve racial equality in educational institutions by "natural representation, as opposed to artificial manipulation." Currently, in evaluating levels of minority enrollment in universities, the question to be answered is: How can admissions processes be changed to achieve diversity? This Note attempts to demonstrate that the better question is: What is causing this disparity to occur in the first place, and how can we fix it?

Part I will give an overview of the current state of race-based affirmative action plans and how the Supreme Court's decisions in Grutter v. Bollinger and Gratz v. Bollinger affect these plans. Part II discusses some proposed race-neutral alternatives to traditional affirmative action plans, including percentage plans and economic affirmative action, both of which are applied during the admissions process at the university level. Part III gives an overview of the types of education finance reform that have been attempted thus far across the country and how this reform will contribute greatly to diversity at the university level. This part examines the effects of school choice, the use of property taxes to finance public schools, and litigation and legislation mandating minimal standards of education. Part IV discusses the role that the racial achievement gap plays in education reform and what it will take to narrow that gap. Part V brings the above approaches together and proposes a solution using social science methodology. It suggests that alternative dispute resolution processes may be more successful than litigation at affecting a change in the way schools are run; and that such processes must take place in each individual school district as opposed to at a state or national level. This part also suggests a sample model for a solution based on a modified version of Maslow's Hierarchy of Needs.

Finally, this Note concludes by observing that great strides have been made in improving the various aspects of the nation's education system, but

5. See,e.g., Gregory Kane, Affirmative Action? No, Racial Preference, Balt. Sun, June 29, 2003, at 3B; Terence J. Pell, Editorial, Camouflage for Quotas, WASH. Post, June 30, 2003, at A15; Abigail Thernstrom, Opinion, College Rulings Add Insult to Injury; Court's Upholding of Admissions Preference Glosses over Need for Better Early Schooling, L.A. TimES, June 29, 2003, at M1; and Opinion, What Do U-M Court Rulings Mean?, Detroit News, June 24, 2003, at 11 A.

6. Shane H. Freedman, Comment, Affirmative Action: An Idea Whose Time Has Gone, 27 SETON HALL L. REV. 1579, 1621 (1997). 
each attempt, by itself, falls slightly short of its goal of attaining educational equality. Now-in the wake of the Court's decision in Grutter v. Bollinger - is the time to examine those efforts, their shortcomings, and find a way to fix the system in its entirety.

\section{Current Affirmative Action Programs}

\section{A. A Brief History}

Ironically, the term "affirmative action" was initially used in the context of requiring entities that contracted with the federal government to take "affirmative action" to ensure that employees or applicants were treated without regard to factors such as race. ${ }^{7}$ But in the wake of Brown v. Board of Education $^{8}$ and the school desegregation which that case ordered, affirmative action became known as a widely used method for colleges and universities to obtain higher percentages of minorities by taking race into account in the admissions process. ${ }^{9}$

The debate over affirmative action centers on the state's ability to make race a factor in admissions processes. Under standard constitutional analysis, race is a suspect class and thus, all race-based classifications are subject to strict scrutiny. ${ }^{10}$ In other words, the use of race must both (1) serve a compelling state interest; and (2) be narrowly tailored to achieve that interest. ${ }^{11}$ A state actor defending the use of race in its affirmative action program typically cites one of the following as its compelling interest: the achievement of diversity or the remedy of past discrimination. ${ }^{12}$

7. Exec. Order No. 11, 246, 3 C.F.R. 339 (1964-1965).

8. Brown v. Bd. of Educ., 347 U.S. 483 (1954).

9. The scope of this Note is limited to the use of affirmative action in the education, rather than the employment, context. The factors that create disparities in a particular employer's work force, requiring employers to use voluntary affirmative action programs, may be different than those that create disparities in the education context.

10. Adarand Constructors, Inc. v. Pena, 515 U.S. 200, 227 (1995) ("“A]11 racial classifications, imposed by whatever federal, state, or local governmental actor, must be analyzed by a reviewing court under strict scrutiny.").

11. $I d$.

12. Since the focus of this Note is examining the source of the lack of diversity at universities and not remedying the past effects of specific instances of discrimination, the only compelling interest disc ussed is diversity. For a discussion of when remedying past discrimination can be appropriately used as a compelling interest, see Regents of the Univ. of Cal. v. Bakke, 438 U.S. 265, 307 (1978). 
On April 1, 2003, the United States Supreme Court heard oral arguments in both Grutter and Gratz. ${ }^{13}$ These cases involved the University of Michigan's policy of using race as a factor in its admission process in the hope of attaining a diverse student body. ${ }^{14}$ Since diversity was recognized in Justice Powell's opinion for the plurality of the Supreme Court in Bakke as a "constitutionally permissible goal," 15 many schools across the country, including the University of Michigan, have cited diversity as their justification for applying race-based factors. ${ }^{16}$

The Bakke Court held that a university may not achieve the goal of a diverse student body by the use of quotas, i.e., reserving a specific number of seats for minority students, ${ }^{17}$ but may only consider race as a "plus" factor. ${ }^{18}$ By deeming race a "plus" in a particular applicant's file, the school is not insulating that candidate's file from comparison with others and every applicant is considered for all of the available seats. ${ }^{19}$ As an example of a program that would pass constitutional muster, Justice Powell pointed to the program Harvard had in place at the time (the "Harvard Plan"). ${ }^{20}$ The Harvard Plan does not set quotas, but, because "of the necessity of including more than a token number of black students ... pays some attention to ... [ [the] types and categories of students" it admits. ${ }^{21}$

In the years between Bakke and Grutter, a split emerged among courts as to whether Justice Powell's opinion for the plurality in Bakke was binding precedent on the issue of diversity as a compelling state interest. ${ }^{22}$ Last year,

13. Grutter v. Bollinger, 123 S. Ct. 2325 (2003); Gratz v. Bollinger, 123 S. Ct. 2411 (2003).

14. Grutter, 123 S. Ct. at 2331-32; Gratz, 123 S. Ct. at 2419-20. The affirmative action plan applied at the undergraduate school differs from that applied at the law school. The undergraduate program adds twenty points to a minority applicant's overall score, thus changing what scores are required for automatic admission or rejection from the school. Id. at 2419. However, the law school's program only seeks to achieve a certain percentage of minority students in the incoming class, and does so without explicitly adding points to an applicant's score. Grutter, 123 S. Ct. at 2331-32.

15. Bakke, 438 U.S. at 311-12. The "attainment of a diverse student body . . clearly is a constitutionally permissible goal for an institution of higher education." Id.

16. See, e.g., Smith v. Univ. of Wash. Law Sch., 233 F.3d 1188 (9th Cir. 2000); Hopwood v. Texas, 78 F.3d 932 (5th Cir. 1996).

17. Bakke, 438 U.S. at 315.

18. Id. at 317 .

19. $I d$.

20. Id. at 316-17.

21. Id. (alteration in original).

22. Compare Hopwood v. Texas, 78 F.3d 932 (5th Cir. 1996), which held that diversity is not a compelling state interest, with Smith v. Univ. of Wash. Law Sch., 233 F.3d 1188 (9th Cir. 2000), which held that it is. 
the Supreme Court granted certiorari in the cases of Grutter v. Bollinger and Gratz v. Bollinger to resolve this issue. ${ }^{23}$

\section{B. Grutter v. Bollinger ${ }^{24}$}

The plaintiffs in Grutter were white applicants who were denied admission to the University of Michigan Law School and who alleged that the school's affirmative action policy discriminated on the basis of race in violation of the Fourteenth Amendment and Title VII of the Civil Rights Act of $1965 .{ }^{25}$ The policy at issue required admissions officials to consider all of the information in a candidate's file, including the student's undergraduate grade point average (GPA), Law School Admissions Test (LSAT) score, personal statement, and letters of recommendation. ${ }^{26}$ While GPA and LSAT scores were a consideration under the policy, a high score would not guarantee admission, and a low score would not automatically disqualify a candidate. ${ }^{27}$

The admissions policy was designed to "achieve that diversity which has the potential to enrich everyone's education and thus make a law school class stronger than the sum of its parts." 28 Though the school did not limit the types of "diversity contributions" that would be given substantial weight in the admissions process, the policy reaffirmed the school's "longstanding commitment to . . racial and ethnic diversity." 29 The policy placed special importance on the inclusion of students from groups that have been historically underrepresented, "like African-Americans, Hispanics and Native Americans." ${ }^{\prime 30}$ The school did not aim to enroll a particular number of minority students, but rather aimed to have a "critical mass" of underrepresented students. ${ }^{31}$ This "critical mass" was defined by the Director of Admissions as "a number that encourages underrepresented minority students to participate in the classroom and not feel isolated." ${ }^{32}$ Representatives of the school also asserted that a critical mass could not be

23. Grutter v. Bollinger, 123 S. Ct. 617-18 (2002); Gratz v. Bollinger, 123 S. Ct. 602 (2002).

24. Gratz is not discussed here because the Court set forth its rationale for holding that diversity is a compelling state interest in Grutter and applied that same rationale in Gratz.

25. Grutter v. Bollinger, 123 S. Ct. at 2325, 2332 (2003).

26. Id. at 2331-32.

27. Id. at 2332 .

28. Id. (quoting the admissions policy of the University of Michigan Law School)

29. Id. (quoting the admissions policy of the University of Michigan Law School).

30. Id. (quoting the admissions policy of the University of Michigan Law School).

31. Id. at 2333 .

32. Id. 
achieved if the admissions committee relied primarily on GPAs and LSAT scores, without taking race into consideration. ${ }^{33}$ After applying the traditional two pronged strict scrutiny test, the Court held that the school's affirmative action policy both served a compelling interest and was narrowly tailored. ${ }^{34}$

The Court first addressed diversity and, for the first time since Bakke, endorsed Justice Powell's opinion in Bakke, which described diversity as a compelling state interest. ${ }^{35}$ It cited two interrelated reasons for doing so. First, the Court noted that its holding "is in keeping with [the] tradition of giving a degree of deference to a university's academic decisions, within constitutionally prescribed limits. ${ }^{" 36}$ Included in this deference is the freedom of a university to choose its student body and the presumption that, absent a showing to the contrary, good faith on the part of the university is presumed. ${ }^{37}$ The second reason the Court cited for holding that diversity is a compelling state interest is that the educational benefits of diversity cited by the university were substantial. $^{38}$ These benefits include preparing students for a diverse workforce $^{39}$ and ensuring that educational institutions are open to students of all races and ethnicities. ${ }^{40}$

The Court next held that the law school's admissions policy was narrowly tailored and fit into the model that Justice Powell set forth in Bakke. ${ }^{41}$ The school's goal of attaining a critical mass did not amount to a quota, since there was no evidence that the admissions officials were aiming to achieve a particular number of minority students. ${ }^{42}$ As evidence of this, the Court pointed to the actual percentages of enrolled minority students, which varied over the years in question from $13.5 \%$ to $20.1 \%$, numbers the Court thought were inconsistent with a quota. ${ }^{43}$ In addition to the lack of a quota, the admissions program gave individualized consideration to each applicant ensuring "that each applicant is evaluated as an individual and not in a way that makes an applicant's race or ethnicity the defining feature of his or her

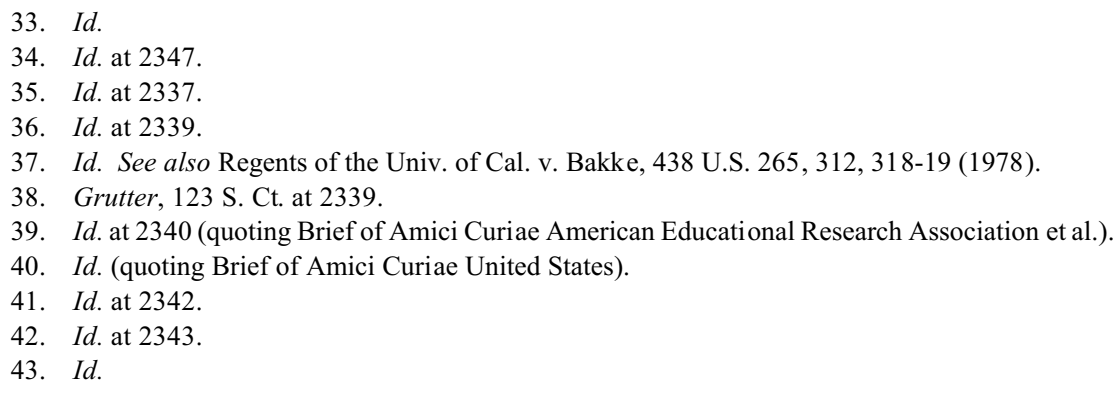


application." ${ }^{44}$ This is in contrast with the program applied at the undergraduate level, at issue in Gratz, which automatically awarded twenty points to an applicant's admissions score based on race. ${ }^{45}$ This award of twenty points effectively served to isolate minority candidates' applications from competition with other students, thereby preventing the program from being narrowly tailored. ${ }^{46}$ The Court struck down the undergraduate program on this basis. ${ }^{47}$ The Grutter Court also held that there was ample evidence that the law school gave considerable weight to diversity factors other than race, including fluency in other languages, overcoming adversity, exceptional community service and established careers in other fields. ${ }^{48}$

The Court also set forth a brief discussion of race-neutral alternatives to race-based affirmative action policies and asserted that the race-based policies approved in its decision must be limited in time. ${ }^{49}$ The race-neutral alternatives that the Court mentioned were a lottery system, the lowering of admissions standards, and percentage plans. ${ }^{50}$ The Court found a common problem with all three: each would force the school to sacrifice its educational mission of achieving all kinds of diversity, not just racial diversity. ${ }^{51}$ However, it subsequently recognized the importance of raceneutral alternatives when it stated that race-based affirmative action programs must have a "logical end point." 52 "Universities in California, Florida, and Washington State, where racial preferences in admissions are prohibited by state law, are currently engaged in experimenting with a wide variety of alternative approaches. Universities in other states can and should draw on the most promising aspects of these race-neutral alternatives as they develop." ${ }^{, 53}$ It is with a vision toward the end of race-based affirmative action that this Note continues.

44. Id.

45. Id. For more details of the affirmative action policy applied at the undergraduate level of the University of Michigan see Gratz v. Bollinger, 123 S. Ct. 2411, 2418-20 (2003).

46. Gratz, 123 S. Ct. at 2427-28.

47. $I d$.

48. Grutter, 123 S. Ct. at 2344.

49. Id. at 2344-47.

50. $I d$.

51. Id. at 2345 .

52. Id. at 2346 .

53. Id. 


\section{Race-Neutral Affirmative Action Plans}

The two most commonly offered alternatives to race-based affirmative action plans are percentage plans and economic affirmative action; both raceneutral attempts at achieving diversity. Though each is discussed separately below, it should be kept in mind that a holistic approach to diversity may require taking aspects of each plan and using them together. A third alternative to traditional affirmative action plans is to apply race-based preferences at the primary school level instead of the undergraduate level. ${ }^{54}$ Because this Note proposes that diversity can be achieved without race-based preferences, this option is not addressed.

\section{A. Percentage Plans}

A few states have abolished race-based affirmative action plans and replaced them with what are commonly referred to as percentage plans. ${ }^{55}$ Though the specifics of each plan vary by state, the basic structure of each plan is that the top ranking seniors of every high school in the state automatically gain admission to state colleges and universities, regardless of the students' scores on standardized tests such as the SAT or ACT, and also regardless of their race. ${ }^{56}$

Percentage plans were first used by California's state university system as early as 1960 , but only in conjunction with race-based affirmative action programs. ${ }^{57}$ That plan, not mandated by the state, provided automatic admission into the state university system for students who were among the

54. The question of whether diversity is a compelling interest at the primary school level was not addressed by the Supreme Court and thus remains undecided. For a discussion of diversity at the primary school level, see generally Note, The Constitutionality of Race-Conscious Admissions Programs in Public Elementary and Secondary Schools, 112 HARV. L. REV. 940 (1999) (arguing that race-based admissions programs for elementary and secondary schools should survive strict scrutiny because the special characteristics of those schools make achieving a diverse student body a compelling interest).

55. Though there are several states that now prohibit the consideration of race in admissions procedures, the only three examined in this note are California, Texas, and Florida.

56. In each of these states, California, Florida, and Texas, students retain the option of traditional admission procedures which use a student's GPA and standardized test scores to determine eligibility for admission. For a fuller discussion of the percentage plans imposed in each of these three states, see U.S. Commission on Civil Rights, Beyond Percentage Plans: The Challenge of Equal Opportunity in Higher Education, at http://www.usccr.gov (last visited Jan. 9, 2004) [hereinafter Beyond Percentage Plans].

57. $I d$. 
top $12.5 \%$ of high school graduates statewide. ${ }^{58}$ In addition to that, the university would offer admission to the top $4 \%$ of graduates from every high school in the state. ${ }^{59}$ In 1996, these programs became the sole form of affirmative action when California voters passed Proposition 209, which amended the state's constitution to prohibit race-based affirmative action programs. ${ }^{60}$

Texas followed suit in 1998 after the Fifth Circuit's decision in Hopwood v. Texas, which held that diversity was not a compelling state interest. ${ }^{61}$ The Hopwood holding thus prohibited race-based preferences in the state. ${ }^{62}$ The Texas legislature enacted the state's percentage plan in response. Under the Texas plan, if an applicant to a Texas state college or university graduated high school with a grade point average in the top $10 \%$ of his or her class, that applicant had to be admitted to the school, regardless of standardized test scores. ${ }^{63}$

One year later, Florida instituted its Talented 20 Program. ${ }^{64}$ Florida's statute provides that a student who graduated from one of Florida's public high schools in the top $20 \%$ of his or her class and who provided standardized test scores, must be admitted to a university in the state system, regardless of what his or her standardized test scores are. ${ }^{65}$

58. $I d$.

59. $I d$.

60. CAL.Const. art. I, $\S 31$ (a) reads: "The state shall not discriminate against, or grant preferential treatment to, any individual or group on the basis of race, sex, color, ethnicity, or national origin in the operation of public employment, public education, or public contracting."

61. Hopwood v. Texas, 78 F.3d 932, 945 (5th Cir. 1996).

62. See id.

63. Tex. Educ. Code AnN. § 51.803(a) (2003) provides:

Each general academic teaching institution shall admit an applicant for admission to the institution as an undergraduate student if the applicant graduated with a grade point average in the top $10 \%$ of the student's high school graduating class in one of the two school years preceding the academic year for which the applicant is applying for admission and the applicant graduated from a public or private high school in this state accredited by a generally recognized accrediting organization or from a high school operated by the United States Department of Defense.

64. The program was initiated by Governor Jeb Bush when he signed Exec. Order No. 99-281, available at http://sun6.dms.state.fl.us/eog_new/eog/orders/1999/november/eo99-281.html (last visited Jan. 9, 2004), which banned the use of race or ethnicity in university admissions decisions in the State of Florida.

65. Fla. Admin. Code Ann. r. 6C-6.002(5) (2003) provides:

A student applying for admission who is a graduate of a public Florida high school, has completed nineteen required high school units, . . ranks in the top $20 \%$ of his/her high school graduating class, and who has submitted test scores from the Scholastic Assessment Test of the College Entrance Examination Board or from the American College Testing program shall be admitted to a university in the State University System. 
While these plans propose a "blind" admissions process, they are fairly new and it is not yet clear whether they will be effective in achieving meaningful levels of diversity. In addition, upon further examination, their flaws are apparent and troublesome.

First, these plans only provide a basis for admission to undergraduate schools, leaving admission to graduate schools unaddressed. ${ }^{66}$ The Supreme Court took note of this in Grutter, and further commented that "even assuming such plans are race-neutral, they may preclude the university from conducting the individualized assessments necessary to assemble a student body that is not just racially diverse, but diverse along all the qualities valued by the university." ${ }^{67}$ As medical and law schools have been a major source of the litigation that has ensued over affirmative action policies, ${ }^{68}$ one has to wonder how the goal of diversity at these institutions will be achieved. Graduate schools, especially specialized schools that train for a particular profession, like law or medicine, may rely heavily on standardized test scores, such as the LSAT or MCAT, to predict the future success of applicants. Without racebased preferences, graduate schools are likely to place even more weight on standardized testing, which tends to produce lower scores for minorities. ${ }^{69}$ This extra reliance on numbers will likely cause any level of diversity the school has currently attained to drop quickly. ${ }^{70}$

As author Michelle Adams pointed out, a second problem with these plans is that they rely on the segregation of the state's high schools for their success. ${ }^{71}$ For example, if there are ten high schools in a given locality, and five of those (50\%) are attended primarily by a given minority, if the top $10 \%$ of all ten schools is offered automatic admission, $50 \%$ of those students likely will be minorities. Percentage plans do not attempt to remedy the problem of segregation that exists in many areas around the country. Therefore, if a

66. Though none of the legislation mandating these programs speaks directly to the issue of graduate admissions, the language does refer to percentages of high school classes, not undergraduate classes, thus allowing an inference regarding inapplicability to graduate schools to be made. See CAL. Const. art. I, $\S 31$ (a); Fla. Admin. Code Ann. r. 6C-6002(5) (2003); Tex. Educ. Code Ann. § 51.803(a) (2003). Additionally, the Supreme Court in Grutter refused to consider percentage plans as a feasible race-neutral alternative to race-based affirmative action because of the failure of the plans to describe their applicability at the graduate school level. Grutter v. Bollinger, 123 S. Ct. at 2325, 2345 (2003).

67. Grutter, 123 S. Ct. at 2345.

68. See Regents of the Univ. of Cal. v. Bakke, 438 U.S. 265 (1978); Smith v. Univ. of Wash. Law Sch., 233 F.3d 1188 (9th Cir. 2000); and Grutter, 123 S. Ct. at 2325.

69. See discussion of the achievement gap infra Part IV.

70. See discussion of the achievement gap infra Part IV.

71. Michelle Adams, Isn't It Ironic? The Central Paradox at the Heart of "Percentage Plans," 62 Оніо Sт. L.J. 1729, 1734 (2001). 
state's high schools were to be integrated, the results with the percentage plan are likely to be the same in terms of racial diversity, as they would be without any affirmative action plan. ${ }^{72}$

The possibility of dramatic decreases in minority enrollment is another key criticism of percentage plans. None of the plans currently in place address what happens if minority populations at the university level drop. ${ }^{73}$ In light of these concerns, some effort has been made to determine the effectiveness of these plans in achieving diversity. ${ }^{74}$ While the results vary from state to state and from study to study, some observations can be made. First, a recurring problem is that even though percentage plans make more minorities eligible for admission to state universities, only a fraction of those students apply for admission and even less actually enroll. ${ }^{75}$ One author reports that $60 \%$ of African American students in Texas who attend college do so out of state. ${ }^{76}$ Additionally, even if students do remain in the state for undergraduate education, many students find that schools in the state university system are either too far away or too expensive when compared with their local community colleges. ${ }^{77}$

Since percentage plans are still fairly new, it is best to assume that the list of problems above is not all-inclusive. ${ }^{78}$ One study showed that sole reliance on percentage plans to achieve diversity may backfire. A report compiled by the United States Civil Rights Commission revealed several problems. First, some students who meet eligibility requirements under percentage plans attend

72. See id.

73. See Cal. Const. art. I, § 31(a); Fla. Admin. Code AnN. r. 6C-6002(5) (2003); Tex. Educ. Code AnN. § 51.803(a) (2003).

74. Beyond Percentage Plans, supra note 56; William E. Forbath \& Gerald Torres, Merit and Diversity After Hopwood, 10 Stan. L. \& Pol'y Rev. 185 (1999); David Montejano, Ph. D., Access to the University of Texas at Austin and the Ten Percent Plan: A Three Year Assessment, at http://www.utexas. edu/student/research/reports/admissions/Montejanopaper.htm (last visited Jan. 9, 2004); Statistics for minority enrollment at the University of California can be found on its website, University of California Freshman Admits from California Fall 1997 through 2002, at http://www.ucop.edu/news/factsheets/2002/ admissions_ethnicity.pdf (last visited Jan. 9, 2004); Statistics for the State of Florida can be viewed at New FTIC Minority Students Enrolled Summer and Fall Terms, available at http://www.myflorida.com/ myflorida/government/otherinfo/ppts/enrollment2.ppt (last visited Jan. 9, 2004).

75. See Forbath \& Torres, supra note 74, at 187; see also Samuel Autman, Minority Admissions Up at UC Campuses, SAN Diego Union-TRIB., Apr. 4, 2001, at A3.

76. Forbath \& Torres, supra note 74 , at 190 n.26.

77. Id. at 187 .

78. For example, one possible problem that has yet to be seen is that state schools which were considered competitive prior to percentage plans may be seen as less competitive. This is especially true for those schools which traditionally require high SAT scores for admission. If the public makes the presumption that these competitive state schools are now less prestigious it could create a market for private schools, and consequently drive up the price of undergraduate education. 
failing high schools and may not be prepared for the academic demands of college. ${ }^{79}$ In response to this, schools may require students who do not meet minimum standards on preliminary testing to enroll in summer preparatory courses. However, this may only serve to further intimidate such students and discourage them from attending. On the opposite end of the spectrum, students in competitive high schools whose grades put them just beyond eligibility requirements wind up competing for limited seats, when they may have easily qualified if they attended a less competitive neighboring school. ${ }^{80}$ A second problem that the study uncovered is that it may be safe to assume that most of the students in the top percentages of their high schools would have gained admission to state universities even without percentage plans. ${ }^{81}$ Consequently, the use of percentage plans at some schools does not have any greater effect on minority enrollment at undergraduate institutions than the use of standard admissions procedures, such as GPA and SAT scores. Students in the top $10 \%$ of their class are the same students with the highest GPAs and SAT scores. ${ }^{82}$ However, percentage plans may have a big effect at schools that function with below average standards, where students may not be prepared to compete with students from better schools on standardized tests. ${ }^{83}$

However, it remains to be seen what weight will be assigned to these problems and what solutions will be proposed to counter them. Some of these problems may be alleviated if states were to supplement percentage plans with other initiatives, such as replacing the use of standardized testing with more comprehensive admissions processes, and increasing the use of programs that reach socially and economically disadvantaged students.

\section{B. Economic Affirmative Action}

In addition to percentage plans, some have suggested that universities should give more weight to an applicant's socioeconomic background in the admissions process. Unlike race, class or socioeconomic status is not a protected class and classifications that discriminate on the basis of wealth are therefore not subject to strict scrutiny. ${ }^{84}$ The premise of economic affirmative

79. Beyond Percentage Plans, supra note 56, Chapter 6.

80. Id.

81. Id.

82. But see Adams, supra note 71 (arguing that percentage plans will succeed in achieving higher levels of minority enrollment where high schools remain segregated).

83. On the other hand, these students are the same ones that may be less prepared for college and thus required to attend summer sessions as a condition of their admission to state schools.

84. See San Antonio Indep. Sch. Dist. v. Rodriguez, 411 U.S. 1 (1973). 
action is that due to the often high correlation between minorities and low socioeconomic status, using socioeconomic status as a plus factor in admissions may contribute towards creating a diverse student body. ${ }^{85}$

Supreme Court Justices Clarence Thomas and Antonin Scalia, prior to their ascension to the bench, both articulated their approval of this idea. Justice Thomas was of the opinion that economic-based affirmative action, unlike race-based affirmative action, responds directly to "burdens that have been unfairly placed in ... individual's paths." ${ }^{186}$ In his critique of race-based affirmative action plans, Justice Thomas goes on to note that " $[t]$ he temptation to do things the easy way is always great, but before we succumb we should remember these victims, and then choose the tougher course that promises to yield genuine and lasting equal opportunities." ${ }^{87}$ Justice Scalia also stated his approval of economic affirmative action: "I strongly favor-what might be called ... 'affirmative action programs' of many types of help for the poor or disadvantaged." ${ }^{88}$ But critics of economic affirmative action are worried that distinctions based strictly on socioeconomic status may be overbroad.

Professor Richard Fallon of Harvard Law School questions whether this type of affirmative action program should be based on economic criteria alone, or whether it should include another inquiry into the presence of conditions commonly associated with poverty. ${ }^{89}$ He notes that "not all of the disadvantages associated with poverty are caused or constituted by poverty." $" 90$ Some of the disadvantages typically associated with severely impoverished conditions include below average physical health and development, ${ }^{91}$ slow intellectual development, ${ }^{92}$ and underdeveloped character and work habits. ${ }^{93}$ However, as Professor Fallon observes, a student could grow up in a very poor family that provides a nurturing environment resulting in the development of

85. See generally Richard H. Fallon, Jr., Affirmative Action Based on Economic Disadvantage, 43 UCLA L. REv. 1913 (1996) (discussing three types of affirmative action: merit-based, transformative, and non-merit-based).

86. Clarence Thomas, Affirmative Action Goals and Timetables: Too Tough? Not Tough Enough, 5 YALE L. \& POL'y REV. 402, 410-11 (1987) (“'A]ny preferences given should be directly related to the obstacles that have been unfairly placed in those individual's paths, rather than on the basis of race or gender, or on other characteristics that are often poor proxies for true disadvantage.").

87. Id. at 411

88. Antonin Scalia, The Disease as Cure: "In Order to Get Beyond Racism, We Must First Take Account of Race," 1979 Wash. U. L.Q. 147, 156 (1979).

89. Fallon, supra note 85 , at 1926-27.

90. Id. at 1926 .

91. Id. at 1925

92. Id. at $1925-26$.

93. Id. at 1926 . 
positive character traits and a strong work ethic. ${ }^{94}$ "Conversely, someone growing up in a household well above the poverty line could encounter some of the most important disadvantages commonly linked to poverty." 95 But Professor Fallon also expresses the concern that economic affirmative action plans may not accurately compensate for these disadvantages if they grant preference based on current economic conditions determined through something like submission of tax returns. ${ }^{96}$ However, this concern may be somewhat alleviated through the use of admissions essays, which provide the applicant with an opportunity to describe circumstances not easily ascertained through the application itself, such as childhood poverty.

In addition to just taking socioeconomic status into account at the college admissions stage, programs that work with students from low income backgrounds throughout primary school, to prepare them for a college education, must also be utilized. The Higher Education Act of $1965^{97}$ created the TRIO programs (initially there were only three) which provide disadvantaged students with educational support. ${ }^{98}$ TRIO now consists of many different programs designed to meet the needs of low income and disabled students. ${ }^{99}$ Beginning with students in the sixth grade, the Talent Search program provides educational counseling to approximately 2,000 students. ${ }^{100}$ One of the better known TRIO programs is Upward Bound, which provides tutoring, counseling, and other services to high school students from low income families or potential first-generation college students. ${ }^{101}$ Upward Bound only counsels about sixty students, but works with them for longer

\section{Id.}

95. Id.

96. Id. at 1927. "[M]any of the disadvantaging conditions associated with poverty specifically involve childhood poverty, not present economic status." Id.

97. Higher Education Act of 1965, Pub. L. No. 89-329, 79 Stat. 1219 (codified as amended in scattered sections of 20 U.S.C. (2001)).

98. Council for Opportunity in Education, What is TRIO?, at http://www.trioprograms.org/ abouttrio.html (last visited Jan. 9, 2004).

99. These include Talent Search, Upward Bound, Upward Bound Math Science, Veteran's Upward Bound, Student Support Services, Educational Opportunity Centers and the Ronald E. McNair PostBaccalaureate Achievement Program. Id.

100. $I d$.

101. Christian Sundquist, Equal Opportunity, Individual Liberty, and Meritocracy in Education: Reinforcing Structures of Privilege and Inequality, 9 GEO. J. ON POVERTY L. \& POL'Y 227, 244-45 (2002). See also U.S. Department of Education, A Profile of the Federal TRIO Programs: 2002, available at http://www.ed.gov/programs/triotrain/trioprofilebrochure2002.pdf(last visited Jan. 9, 2004); Teresa Moore, Concern for Upward Bound Program Cuts Feared in Highly Successful Class Based College Prep Project, San Fran. Chron., Aug. 14, 1995, at A13. 
periods of time than students in other TRIO programs like Talent Search. ${ }^{102}$ These programs are valuable, but are not enough. One author notes that these programs, "by focusing solely on expanding opportunity for underprivileged students . . . fail to limit the effects of background conditions." 103 In other words, despite an individual student's motivation to achieve and academic ability relative to the other students in his or her school, that student may still not succeed in attending college if he or she attends a failing high school and is burdened with those disadvantages traditionally associated with impoverished conditions. Essentially, these programs "end up reifying privilege by creating an illusion of equal opportunity." 104

These programs may best be considered in the context of an individual community's particular needs. Federal programs, while serving an important function, cannot cater to each community's or, for that matter, each family's educational needs. Supplemental educational and mentoring programs are an important part of any effort to reform an education system.

\section{Reforming the Nation's Education System}

The conditions in which many of the nation's students attend school are deplorable. ${ }^{105}$ As it stands, there are students who attend schools in urban areas which are overcrowded and understaffed. ${ }^{106}$ The problem is exacerbated when many children do not even have books ${ }^{107}$ and attend school in buildings

102. Sundquist, supra note 101, at 245.

103. Id. at 246 .

104. $I d$.

105. See generally Jonathan Kozol, Savage Inequalities: Children In America's Schools (1991) (documenting the conditions that children face in impoverished inner city schools throughout the country).

106. Kozol describes his encounter with a teacher in Irvington, New Jersey who stated:

[E]leven classes in one school don't even have the luxury of classrooms. They share an auditorium in which they occupy adjacent sections of the stage and backstage areas. "It's very difficult ... to have concert rehearsals with the choir" while ten other classes try to study in the same space. "Obviously. . . there is a problem with sound ...."

"I'm housed in a coat room," says a reading teacher at another school in Irvington. "I teach," says a music teacher, "in a storage room." Two other classes, their teachers say, are in converted coal bins. A guidance counselor says she holds her parent meetings in a closet. Id. at 159 .

107. An eleventh grade student in Camden, New Jersey describes her experience: You see this book? [The student displayed a paperback book with no cover and pages falling out]. We have to read Charles Dickens. That's the book they gave me. Pages are missing. ... We don't even have enough for every student. There are just ten students in the class! ... Ten people! They had only seven books! Why are we treated like this?

Id. at 154 . 
that are unsafe. ${ }^{108}$ The results of these conditions are clear: students walk away from their primary school education with lower than average reading skills and overall poor academic performance. ${ }^{109}$

But the path leading toward the goal of attaining a completely equal education system contains many substantial "social" obstacles. The first of these is wrapped around the Establishment Clause. Many attempts at reform involve removing children from failing public schools and placing them in private schools; a move many see as religiously motivated. A second obstacle to equal education, what I refer to as the "Robin Hood Phenomenon," has reared its head in education finance litigation. Most education finance reform platforms suggest that the excess funds from wealthier school districts should be used to fund poorer school districts. This "rob the rich to feed the poor" approach requires some individuals to take responsibility for the acts or misfortunes of others. Concepts of individual autonomy may be at odds with such distributive approaches.

Despite these obstacles, parents of students in failing schools, in conjunction with state legislatures, have made continued efforts to improve their children's education by trying one thing at a time. The first step was to offer parents increased options in terms of choosing to which schools they can send their children. ${ }^{110}$ Some parents, who refused to send their children to other schools or for whom "school choice" was impractical, initiated litigation seeking more money to improve the schools their children already attended. ${ }^{111}$ If attempts at achieving equalized funding were unsuccessful, some parents sought to establish a state mandated minimumlevel of education, below which the schools could not go. ${ }^{12}$ The pros and cons of each of these approaches are outlined in separate sections below, but each effort at reform should be viewed

108. A teacher at a Bronx high school notes that the school "does everything an inanimate object can do to keep children from being educated." Id. at 99. Kozol describes:

Blackboards ... are "so badly cracked that teachers are afraid to let students write on them for fear they'll cut themselves. Some mornings, fallen chips of paint cover classrooms like snow . . . . Teachers and students have come to see humor in the waterfall that courses down six flights of stairs after a heavy rain."

One classroom . . . has been sealed off "because of a gaping hole in the floor." In the band room, "chairs are positioned where acoustic tiles don't fall quite so often." In many places, "plaster and ceramic tile have peeled off" the walls, leaving the external brick wall of the school exposed. Id. at 99-100 (quoting Overview of Morris High School, N.Y. TimEs, Dec. 10, 1988).

109. 136 Cong. Rec. S14991 (1990) (discussing the Urban Schools of America Act, § 3183).

110. See infra Part III.A.

111. See infra Part III.B.

112. See infra Part III.B. 
as important as the others, with a goal of integrating these approaches kept in mind.

\section{A. School Choice}

To date, there have been several attempts to equalize educational opportunities among different races and classes by providing parents with a choice of schools for their children to attend. ${ }^{113}$ School choice plans can be traced back to the years following Brown v. Board of Education, ${ }^{114}$ when parents were given the choice of removing their children from poor, ineffective, or segregated schools, and moving them to more effective, wealthier, or integrated schools. ${ }^{115}$ But simply providing the choice to parents may not be enough. ${ }^{116}$ The ability of many families to participate in school choice programs is often affected by two things: money and insufficient options. ${ }^{117}$

John Goodman, President of the National Center for Policy Analysis, offers an example of how the school choice problem begins:

$[\mathrm{N}]$ ot all families can afford to participate in the current system. A study by researchers at Southern Methodist University and the Federal Reserve Bank of Dallas found that North Dallas houses near higher-ranking elementary schools sold for about twenty percent more than houses near lower-ranking schools. The authors conclude that the market for education works surprisingly well. Parents can discern the quality and the market charges a premium for it.

This conclusion is supported by an informal survey ... of housing prices in Highland Park - a wealthy Dallas suburb. Most Highland Park homes are inside the Highland Park Independent School District (HPISD); however, a few are in the Dallas Independent

113. See generally Joseph P. Viteritti, Choosing Equality: School Choice, the Constitution, AND CIVIL SociETy (1999) (examining numerous systems of school choice and how choice affects the educational system).

114. Brown v. Bd. of Educ., 347 U.S. 483 (1954).

115. See Brian P. Marron, The Final Reform: A Centrist Vision of School Choice, 8 Geo. J. on POVERTY L. \& POL'Y 321, 327 (2001).

116. Despite the mandate by the Supreme Court in Brown v. Board of Education in 1955 that schools desegregate "with all deliberate speed," many of the nation's schools are stillunder the Court's supervision. Brown v. Bd. of Educ., 349 U.S. 294, 299-301 (1955), quoted in Bd. of Educ. v. Dowell, 498 U.S. 237, 248 (1991). Further, those that have been released from court supervision have merely been declared "unitary," meaning the school is relieved of its duty to desegregate because it has complied in good faith with the court orders and has eliminated "the vestiges of past discrimination ... to the extent practicable." Dowell, 498 U.S. at 249-50. But clearly this is not enough to achieve integrated schools and most of the nation's children are still learning in segregated environments.

117. See generally John C. Goodman, School Choice vs. School Choice, 45 How. L.J. 375 (2002) (arguing that America's school choice system is unfair and inefficient and in effect discriminates on the basis of wealth and race). 
School District (DISD). [A]ll else being equal, homes on the HPISD side of the street sell for twenty-four percent more than those on the DISD side. This implied that many Highland Park homeowners were paying \$72,000 just for the right to send their children to Highland Park schools. ${ }^{118}$

This example demonstrates how the housing market is inextricably intertwined with any given area's system of school choice. Parents with enough money can theoretically choose any school district among a number in their state. ${ }^{119}$ But what about those for whom school choice is impractical?

\section{i. Charter Schools}

Some parents, for whom the choices of schools in their area were insufficient, created their own schools. In order for a charter school to be created, the state must pass a law permitting charter schools and the school must have a sponsoring group. ${ }^{120}$ This group could be educators, parents, a non-profit agency or other group that gets the state's approval. ${ }^{121}$ This newly created school is given great autonomy in terms of enrollment, dress codes, length of the school day, and most things that are usually determined by local school boards. ${ }^{122}$ But in return, it will be held accountable for meeting certain standards, usually relating to academic or financial criteria. ${ }^{123}$ If the school defaults from the standards set by the state, its charter may be revoked. ${ }^{124}$ Funding for these schools is typically taken from the local public school system in proportion to the number of students enrolled. In other words, charter schools could be created if a group of parents in a local public school system decide they want to take the per pupil expenditures that the school district allocates for each of their children and start a new school. ${ }^{125}$

118. Id. at $375-76$.

119. Id. at 375 .

For example: a typical family living in Dallas can choose to live in any of the seventy-nine school districts within fifty miles of downtown Dallas. If each district has at least two campuses at each grade level, a typical family has a choice of about 158 public schools - provided the parents can Id.

afford to buy a house in any neighborhood and are willing to drive a considerable distance to work.

120. ViteritTI, supra note 113 , at 65.

121. Id.

122. Id. Some charter schools may be released of all local regulations except for those pertaining to civil rights, health, and safety. Id.

123. Id.

124. Id. For example, in 1995, a Los Angeles charter school, Edutrain, had its charter revoked for financial mismanagement. Id.

125. Magnet schools are an additional option available in some areas. These schools tend to have concentrated curriculum, such as math or science, and are developed with one or both of two goals in mind: 
While charter schools provide incentive for both the charter school and the remaining schools to improve standards and attract students, the previously existing public schools are left without adequate funding to do so. Furthermore, not all state legislatures permit charters, causing charter schools to be clustered in certain areas around the country. ${ }^{126}$ As such, this option is not yet available to everyone.

\section{ii. Vouchers}

Vouchers are, on their face, a seemingly simple solution to the problem of failing public schools. The standard voucher program provides a designated amount of money for each child's education at the private or public school of his or her choice. ${ }^{127}$ Vouchers purport to provide families, who otherwise could not afford a private school education, with the opportunity to send their children to these schools. The Supreme Court recently upheld the constitutionality of vouchers in the face of First Amendment Establishment Clause challenges in Zelman v. Simmons-Harris. ${ }^{128}$

At issue in Zelman was a program initiated by the State of Ohio that provided financial assistance to families in any school in Cleveland which was under the state's control. ${ }^{129}$ The two types of assistance offered were tuition aid for students to attend the private school of the parent's choice, or tutorial aid for students who chose to remain in public schools. ${ }^{130}$ In the 1999-2000 school year, forty-six of the fifty-six private schools that participated in the program were religiously affiliated. ${ }^{131}$ The program was challenged by a group of taxpayers who claimed that it violated the Establishment Clause of the First Amendment because it had the primary effect of advancing

creating a place for students who are focused on certain areas to develop those skills, and also to attract minorities. Critics of magnet schools complain that too much funding goes to magnet schools to develop unique programs, when that funding could have been spread among schools with inadequate funding. For additional discussion, see Kimberly C. West, A Desegregation Tool that Backfired: Magnet Schools and Classroom Segregation, 103 YALE L.J. 2567 (1994).

126. In 2000, there were 2,069 charter schools operating in the U.S., but over half of those schools were found in five states: Arizona, California, Michigan, Texas, and Florida. Goodman, supra note 117, at 380 .

127. Martha M. McCarthy, Zelman v. Simmons-Harris: A Victory for School Vouchers, 171 ED. LAW REP. 1 (2003).

128. Zelman v. Simmons-Harris, 536 U.S. 639 (2002).

129. Id. at $644-45$.

130. Id. at 645 .

131. Id. at 647. 
religion. ${ }^{132}$ The Supreme Court held that "any objective observer familiar with the full history and context of the Ohio program would reasonably view it as one aspect of a broader undertaking to assist poor children in failed schools, not as an endorsement of religious schooling in general." ${ }^{133}$ The Court further noted the distinction between programs that provide aid directly to religious schools and those in which government aid only reaches religious schools as a result of the independent choices of private individuals. ${ }^{134}$

Though voucher programs may be constitutional, they are not without their problems. Primarily, vouchers may not be offered to all students. Under the Ohio plan at issue in Zelman, only children who attend "failing" ${ }^{135}$ schools are provided with vouchers. But how many students in schools that are under par but yet do not qualify as "failing" are left behind? This issue may have been partially addressed with the No Child Left Behind Act. ${ }^{136}$ Enacted in 2002 by President George W. Bush, this Act provides that a school which does not meet its annual progress objectives must provide educational options to its students. ${ }^{137}$ The Act essentially forces schools in failing districts to adopt programs similar to the voucher program in Zelman. But another problem with voucher programs remains. Many families, even after they receive vouchers, will still be financially unable to send their children to private schools. Most vouchers do not provide parents with the entire tuition amount for a private school; parents must come up with the balance. For example, in Zelman, families whose income falls below $200 \%$ of the poverty line are eligible for $90 \%$ of tuition and the parent's co-payment is limited to $\$ 250 .{ }^{138}$ But all other families are provided with only $75 \%$ of tuition costs and there is no cap on the parents' co-payment. ${ }^{139}$

Though critics have noted that voucher programs may "create government entanglement with religious institutions, increase economic and racial segregation across schools, and have negative consequences for public schools' democratizing function," ${ }^{140}$ they may provide much needed assistance

132. Id. at 648 .

133. Id. at 655

134. $I d$. at 649 .

135. Id. Most states determine which schools are "failing" based on "test scores, attendance, graduation rates and other factors." McCarthy, supra note 127, at 2.

136. No Child Left Behind Act of 2001, Pub. L. 107-110, 115 Stat. 1425 (codified as amended in scattered sections of 20 U.S.C. (2001)).

137. 20 U.S.C. $\S 6316$ (b) (Supp. 2003).

138. Zelman, 536 U.S. at 646.

139. $I d$.

140. McCarthy, supra note 127 , at 1. 
for parents who want to send their children to private schools but cannot afford full tuition. Nonetheless, the central idea behind vouchers, that failing schools will be forced to improve through competition, must be questioned. Failing schools cannot compete when its students, and consequently its funds, are slowly filtered into better schools. In essence, by moving children to better schools, the possibility of improving these failing schools is foreclosed. Not every parent has been willing to give up so easily; efforts to improve existing schools have been undertaken for years.

\section{B. Finance Reform}

School financing schemes were first challenged in the 1960s in response to the "white flight" and population shifts that occurred after the desegregation orders of Brown v. Board of Education. ${ }^{14}$ The primary argument of those seeking finance reform is that relying on local property taxes to fund local public schools is inherently unfair and violates the Equal Protection Clause of the Fourteenth Amendment. ${ }^{142}$ Essentially the problem is that school districts with low tax bases can never raise money in amounts comparable to wealthy districts, no matter how high their tax rates. Since the Supreme Court in Brown based its decision and desegregation orders on the importance of education, ${ }^{143}$ it seemed logical to many that education would be declared a fundamental right under the United States Constitution. Deprivation of such right would, therefore, be subject to strict scrutiny. In 1971, the California Supreme Court adopted this approach in striking down the state's school financing system in Serrano v. Priest. ${ }^{144}$ The court stated that the current system "conditions the full entitlement to [education] on wealth, classifies its recipients on the basis of their collective affluence and makes the quality of a child's education depend . . . ultimately upon the pocketbook of his parents." Henceforth, the court held that the financing system did not survive strict scrutiny because it was not necessary to the attainment of any compelling state interest. ${ }^{145}$ What seemed like a simple solution to a nationwide problem was quickly struck down by the United

141. See Kelly Thompson Cochran, Beyond School Financing: Defining the Constitutional Right to an Adequate Education, 78 N.C. L. REv. 399, 403-04 (2000).

142. Id. at 403-06.

143. See Brown v. Bd. of Educ., 347 U.S. 483, 493 (1954).

144. Serrano v. Priest, 487 P.2d 1241, 1258 (Cal. 1971).

145. Id. at 1263 . 
States Supreme Court in the landmark school financing case, San Antonio Independent School District v. Rodriguez. ${ }^{146}$

\section{i. The Roadblock Set By Rodriguez}

In Rodriguez, parents of students in an urban school district in San Antonio brought a class action suit on behalf of all school children who resided in poor areas with low property tax bases, alleging that Texas's school financing system was unconstitutional under the Equal Protection Clause of the United States Constitution. ${ }^{147}$ Under the state's current finance system, Edgewood, the plaintiffs' school district, raised twenty-six dollars per student through property taxes. ${ }^{148}$ This number can be compared with $\$ 333$ per student produced in Alamo Heights, the most affluent school district in San Antonio. ${ }^{149}$ After state and federal funds were contributed, these amounts shifted to totals of \$356 per pupil in Edgewood and \$594 per pupil in Alamo Heights. ${ }^{150}$

The district court, relying on decisions by the Supreme Court dealing with the rights of indigents to equal treatment in the criminal process ${ }^{151}$ and wealth discrimination and the right to vote, ${ }^{152}$ concluded that wealth is a suspect class. ${ }^{153}$ It also reasoned, relying on the Supreme Court's affirmation of the importance of education, ${ }^{154}$ that education is a fundamental right. ${ }^{155}$ Consequently, the district court held that Texas's finance system

146. San Antonio Indep. Sch. Dist. v. Rodriguez, 411 U.S. 1 (1973).

147. Id. at 4-6.

148. $I$ d. at 11,12 . The average assessed property value in the plaintiffs' school district was $\$ 5,960$ and the tax rate applied was $\$ 1.05$ per $\$ 100$ in assessed property. $I d$. at 12 .

149. Id. at 12-13. The average assessed property value in Alamo Heights exceeded $\$ 49,000$ and the local tax rate applied was $\$ .85$ per $\$ 100$. Id. at 13 .

150. Id. at $12-13$.

151. Douglas v. California, 372 U.S. 353 (1963) (holding that the State of California's denial of counsel on appeal to indigents violates the Due Process Clause of the Fourteenth Amendment); Griffin v. Illinois, 351 U.S. 12 (1956) (holding that the State of Illinois could not deny indigent criminal defendants certified copies of the trial record that are necessary for the appellate process).

152. Harper v. Va. Bd. of Elections, 383 U.S. 663 (1966). The Court, in holding that the State of Virginia could not require voters to pay a fee to exercise their right to vote, noted that "[1]ines drawn on the basis of wealth or property, like those of race, are traditionally disfavored." Id. at 668 (citations omitted). The Court went on to state that "wealth . . . has, in our view, no relation to voting qualifications; the right to vote is too precious, too fundamental to be so burdened or conditioned." Id. at 670 .

153. Rodriguez v. San Antonio Indep. Sch. Dist., 337 F. Supp. 280, 282-83 (W.D. Tex. 1971)

154. See Brown v. Bd. of Educ., 347 U.S. 483, 493 (1954).

155. See Rodriguez, 337 F. Supp. at 283. 
discriminated on the basis of wealth and was unconstitutional. ${ }^{156}$ The Supreme Court disagreed. ${ }^{157}$

The United States Supreme Court distinguished prior wealth discrimination cases by noting that the district court, in assuming that the school system discriminates on the basis of wealth simply because some people receive a less expensive education than others, largely ignored the "threshold questions [of] ... whether it makes a difference ... that the class of disadvantaged 'poor' cannot be identified . . . and whether the relative - rather than absolute - nature of the asserted deprivation is of significant consequence." 158 In other words, since the finance system does not discriminate against any definable category of indigent persons and since it does not result in a complete deprivation of any benefit, the disadvantaged group is not a suspect class.

Next, the Court addressed the question of whether education is a fundamental right. It stated that deciding whether something is a fundamental right requires determining whether such right can be explicitly or implicitly found in the Constitution. ${ }^{159}$ Without further explanation, the court held that "[e]ducation, of course, is not among the rights afforded explicit protection under our Federal Constitution. Nor do we find any basis for saying it is implicitly so protected." ${ }^{60}$ And with that, education finance litigation alleging violations of the United States Constitution, was essentially put to rest.

\section{ii. The Battle at the State Level}

After the decision in Rodriguez foreclosed the possibility of education being declared a fundamental right under the United States Constitution, litigants tried again at the state level, basing their arguments on state constitutions. ${ }^{161}$

In light of the failure of school finance litigation to improve schools across the board, school litigation proceeded to suits alleging the right to a minimum level of education. ${ }^{162}$ This wave of education cases focuses on whether or not education is a fundamental right under a particular state's

156. Id. at 285 .

157. San Antonio Indep. Sch. Dist. v. Rodriguez, 411 U.S. 1 (1973).

158. Id. at 19.

159. Id. at 33-34.

160. Id. at 35 .

161. Cochran, supra note 141, at 408.

162. See generally id. (tracing the history of school financing litigation and causes of action for failure to provide an adequate education). 
constitution and, if so, whether students have a cause of action for "educational malpractice" when the state's schools fail to educate them. ${ }^{163}$ The degree of success litigants will achieve in adequacy suits may depend on the language in their state constitution. A state constitution that lays out detailed expectations for the state's education system is an efficient tool in this type of litigation. ${ }^{164}$ State standards vary from "high quality," 165 and "efficient system of high quality," 166 to "suitable." 167 The "specific qualitative phrases" used in a state's constitution may effect the success litigants will have in seeking improved education. ${ }^{168}$ Even if plaintiffs can establish that they have the right to a minimal level of education, what steps can the court take to ensure students receive an adequate education?

\section{iii. Kansas: A Model for Change}

In 1992 Kansas enacted the School District Finance and Quality Performance Act (SDF/QPA) ${ }^{169}$ legislation which dramatically altered the state's finance system and has come a long way toward creating an equal educational system. ${ }^{170}$ The early stages of the Act were spearheaded by one man, Judge Terry Bullock. ${ }^{171}$ Judge Bullock had a case before him which challenged the constitutionality of the state's current school finance system, Mock v. Kansas. ${ }^{172}$ In Mock, a consolidated case, taxpayers from several districts were merely seeking changes to certain parts of the school financing system, not the whole thing. For example, one district challenged the state's weighting formulas and another challenged part of the state legislation that capped relief at a certain amount. ${ }^{173}$ Once Judge Bullock realized that the

163. Id. at 400,411 .

164. See generally Robert M. Jensen, Advancing Education Through Education Clauses of State Constitutions, B.Y.U. Educ. \& L.J., Spring 1997, at 1 (1997) (arguing that education litigation is most effective when plaintiffs rely on the education clause in their state's constitution).

165. VA. CONST. art. VIII, $\S 1$.

166. ILl. Const. art. X, § 1 .

167. ME. Const. art. VIII, pt. $1 \S 1$.

168. See Jensen, supra note 164, at 3-7. (2002).

169. School District Finance and Quality Performance Act, Kan. Stat. AnN. §§ 72-6405-72-6440

170. For a full discussion of the history behind the SDF/QPA and Kansas's unique legislative reform, see Charles Berger, Equity Without Adjudication: Kansas School Finance Reform and the 1992 School District Finance and Quality Performance Act, 27 J.L. \& EDUc. 1 (1998).

171. Id. at 1.

172. Mock v. Kansas, Case No. 91-CV-1009 (Shawnee County Ct., Oct. 14, 1991).

173. Id. at 2 . 
entire state's finance system would need to be addressed, he organized a summit in which members of the judiciary, legislature, and executive branch would convene. The alignment of the branches was an unusual event that likely contributed to the quick enactment of the SDF/QPA.

The statute operates quite simply. There is a statutorily set "base state aid per pupil," meaning "an amount of state financial aid per pupil." 174 For example, in 1992 that amount was $\$ 3,600$ per pupil. ${ }^{175}$ The amount of state aid a school district will actually receive depends upon that district's "local effort."176 "Local effort" means the amount a school district raises from its property taxes ${ }^{177}$ which are set uniformly in all districts. ${ }^{178}$ If a given district cannot raise the required $\$ 3,600$ per student, then the state provides the rest. ${ }^{179}$ If a district has raised funds in excess of $\$ 3,600$ it will not be entitled to general state aid. ${ }^{180}$ At that point, with each student having equal funding, weighting factors are applied to account for disparities in each district. ${ }^{181}$ In 1992, the six weighting factors applied were transportation, vocational education, bilingual education, at-risk pupils, low enrollment and school facilities. ${ }^{182}$ The base numbers are then adjusted upward according to a set formula. ${ }^{183}$

The SDF/QPA's effect on the Kansas education system was remarkable. In 1992, school district budgets increased by $\$ 154$ million. ${ }^{184}$ Further, discrepancies in school funding from one school district to the next decreased dramatically. For example, in 1991 "per-pupil expenditures ranged [from one district to the next] from $\$ 2,700$ to nearly $\$ 12,000 . " 185$ However, by 1996 , weighted expenditures were only ranging from $\$ 3,411$ to $\$ 4,532$ per pupil. ${ }^{186}$ But despite this seemly positive outcome, not everyone in Kansas was happy.

174. 1992 Kan. Sess. Laws $280 \S 6(d)$.

175. $I d$.

176. School District Finance and Quality Performance Act, KAN. STAT. AnN. § 72-6416(b) (2002).

177. 1992 Kan. Sess. Laws $280 \S 6(\mathrm{e})$.

178. Id. $\S 27$ (b). Section 27 (b) provides for a tax rate increase to 33 mills in the 1993-94 school year and 35 mills in the 1994-95 school year and thereafter.

179. Id. § 12(b).

180. $I d$.

181. Id. $\S \S 15-23$.

182. $I d$. Special education programs are not included in the weighting formulas because such programs are financed wholly by the state. $I d$. $\S 5(\mathrm{f})$.

183. Id. $\S 6(\mathrm{a}), 3(\mathrm{e}), 7-11$.

184. Berger, supra note 170 , at 32 .

185. $I d$.

186. $I d$. 
Seventeen of the state's over three hundred school districts challenged the SDF/QPA in four separate suits, which were consolidated. ${ }^{187}$ Plaintiffs asserted over twelve separate grounds on which the Act could be struck down including infringement upon local school boards' authority and violations of due process through excessive taking of property. ${ }^{188}$ The state supreme court unanimously upheld all provisions of the Act and observed that "the legislature decided to boldly go where Kansas has never gone before. If experience establishes that the Act needs further revision, the legislature will have ample opportunity to do so ...."189 The court, in following the United States Supreme Court's holding in Rodriguez, ${ }^{190}$ "rejected the proposition that education is a fundamental right in Kansas or that any suspect classifications were implicated by the funding disparities." 191 The use of Rodriguez is noteworthy because the plaintiffs in Rodriguez were arguing that they had a constitutional right to a minimal level of education, where plaintiffs in the Kansas case, were arguing just the opposite: that the SDF/QPA was unconstitutional because it set a maximum level of education.

All three branches of the Kansas state government managed to work together to overhaul the education system and create equality among its students. But this occurrence is unlikely to work as well in other states for several reasons. First, the language of Kansas's Constitution requires the legislature to provide "suitable finance for the educational interests of the state." "192 The constitution's explicit reference to the state's financing system gave both the court and the legislature leverage to declare the current scheme unsuitable and to create one that was suitable. In addition to the help from the constitution, Kansas itself is uniquely situated as it is not burdened with a lot of impoverished urban areas. ${ }^{193}$ As discussed above, because of the large disparities that usually exist between urban and rural areas, a simple funding scheme like the SDF/QPA may not work as well in other states, particularly those with large urban areas. Urban schools would need so much more money than rural ones just to balance out, that rural districts may well have a better case for unconstitutional takings.

\footnotetext{
187. Unified Sch. Dist. No. 229 v. Kansas, 885 P.2d 1170 (Kan. 1994).

188. Id. at 1173 .

189. Id. at 1197.

190. San Antonio Indep. Sch. Dist. v. Rodriguez, 411 U.S. 1 (1973).

191. Berger, supra note 170, at 38-39.

192. KAN. Const. art. 6, §6(b).

193. Berger, supra note 170, at 41 .
} 
Though the Kansas scheme is a good example of what can be accomplished when groups with different interests come together and produce a solution that meets their individual needs, it could have been taken one step further to produce complete success. If the parents and taxpayers had participated in the summit and in the production of the legislation, it is possible that a mutually agreeable solution would have been reached, thus eliminating the need for litigation. Nonetheless, the positive effect of solutions created by a group, rather than just an individual can be seen in the way the Kansas Supreme Court supported the Act (and the legislature) in its decision on the Act's constitutionality. Had the court simply deferred to the legislature in the first place, instead of calling a summit, the solution the legislature proposed may not have been mutually agreeable and thus could have sparked a hostile reaction by the state's supreme court.

Despite the success that Kansas has seen in reforming its education finance scheme, the long term success of increased funding may not solve all of the problems that failing schools face. Some studies suggest that unlimited amounts of money may not help students learn any better. For example, the District of Columbia public school system has the highest per pupil expenditures in the country, ${ }^{194}$ but student performance on standardized tests is among the worst in the country. ${ }^{195}$ However, the effects of adequate funding cannot be ignored altogether. Inevitably, students with books will learn to read better than students without books; and students with lab equipment will learn the fundamentals of chemistry better than those without equipment. Equalized funding may be an important brick in the foundation of a solid education system, but it cannot stand alone.

\section{Narrowing the Achievement Gap}

In a perfect world, every student would have the same quality education and each student would learn the same way. But unfortunately, even if each student is given the same opportunity on its face, there are disparities that lie beneath the surface that are only benefiting few. In terms of achieving a racial balance at the university level, "[a]rguably, a more certain way to ensure that black applicants gain admission to colleges and graduate schools is to narrow the gap between their [standardized] test scores and the test scores of white

194. Goodman, supra note 117 , at 379 . Expenditures are approximately $\$ 8,000$ per student, where the national average is approximately $\$ 6,000$ per student. $I d$.

195. Id. 
applicants." ${ }^{196}$ Asa G. Hilliard, III, an expert in the area of cultural bias in standardized tests, neatly sums up the problem:

Test makers assume that there is a common body of academic content to which every child has been or ought to have been exposed. Since this is not the case, the generic word 'achievement' should be qualified in some way if it is to have scientific meaning. Yet, those who develop tests for profit would find it nearly impossible to admit to the diversity that exists in the human experience. ${ }^{197}$

Hilliard also suggests the use of four criteria that should be considered as part of the development of such achievement tests. First, the content of the tests should match the content of the curriculum that students are taught. ${ }^{198}$ This may seem like an obvious thing to consider, but as Hilliard remarks, "[u]ntil recently, the United States has permitted, even encouraged, a wide diversity in curricular offerings." ${ }^{199}$ A school's curriculum is set by the local government, not the federal government, ${ }^{200}$ meaning that there can be great discrepancies in what students in one state learn compared to what students in a neighboring state learn. However, the achievement of these students is often measured by the same test. A second criterion that Hilliard suggests is the assurance that achievement tests are racially neutral. ${ }^{201}$ Some proposed solutions to this problem include broadening the sample of students upon which standardized tests are created and requiring a more diverse board of test writers and reviewers. ${ }^{202}$ The third criterion suggested builds off the second by requiring tests to include representative samples of the population. ${ }^{203}$ This would ensure minorities are included in test samples. Finally, Hilliard suggests that the tests should take a student's "relative access to knowledge into consideration." 204 As it stands, achievement tests conclude that if a child does not score well, that that child did not master the information taught to him, when in reality, the quality of instruction that students receive varies greatly from school to school.

196. Dora W. Klein, Beyond Brown v. Board of Education: The Need to Remedy the Achievement Gap, 31 J. L. \& EDUC. 431, 447-48 (2002).

197. Asa G. Hilliard, III, Limitations of Current Academic Achievement Measures, in GoING To School: The African-American Experience 135 (Kofi Lomotey ed., 1990).

198. Id. at 137.

199. $I d$. at 135 .

200. Id. at 137.

201. $I d$.

202. Id. at $140-41$.

203. Id. at 138 .

204. $I d$. 
If one takes the discrepancies in standardized testing described above at face value, it is no wonder that race-based affirmative action programs are needed at the university level. More troublesome, however, is what could occur if these discrepancies are not resolved and race is not taken into account in college admissions. Without changes in the cultural biases that exist in the nation's curriculum and in standardized testing, levels of minority enrollment in universities will likely drop back to where they were pre-Bakke, especially if heavy reliance is placed on standardized tests like the SAT, MCAT, or LSAT. ${ }^{205}$

Though an overnight solution is unlikely to occur, a close examination of the curriculum chosen, standardized testing, and learning methods may be a start. ${ }^{206}$ In addition, some strategies that have been successful to date have been reducing class size ${ }^{207}$ creating structured reading programs, emphasizing cognitive skills in pre-school and strengthening the academic abilities of teachers. ${ }^{208}$

\section{Solutions}

The different aspects of the nation's education system: finance, choice, establishing minimum standards, and closing the achievement gap, cannot be dealt with separately in order to completely fix any school district's problems, but rather must be considered together. Such a holistic approach requires the initiative and cooperation of all branches of a state's government in addition to parents, students, teachers, and any other members of the community that are likely to have a stake in the outcome. This approach was almost accomplished in Kansas, but the failure to include more members of the

205. In addition, reliance on these tests as predictors of minority success may be misplaced. One study suggests that African American students' SAT and ACT scores may be inadequate predictors of success in college when the students attended predominantly white schools. However, where these students attended schools where African Americans comprised a majority of the students, their scores were quite accurate predictors of success. Jacqueline Fleming, Standardized Test Scores and the Black College Environment, in Going to School: The African-American Experience 143 (Kofi Lomotey ed., 1990).

206. See generally Going to School: The African-American Experience (Kofi Lomotey ed., 1990) (examining the factors that contribute to the underachievement of African American students); see also The Black-White Test Score Gap (Christopher Jencks \& Meredith Phillips eds., 1998).

207. Klein, supra note 196, at 443-44. "[R] esults from Tennessee's Project STAR (Student-Teacher Achievement Ratio), for example, consistently demonstrate that reducing class size not only improves the academic achievement of all students, but also narrows the achievement gap by benefitting [sic] most those who are achieving at the lowest levels." Id.

208. $I d$. 
community in forming the solution has resulted in a faction of the population seeking to change the legislation in place. ${ }^{209}$

Building on the holistic approach is another approach that I have labeled the "tiered approach." This approach utilizes the combined efforts of both community and government, but is modeled after the social science concept known as Maslow's Hierarchy of Needs. ${ }^{210}$ Maslow's Hierarchy is divided into five levels of needs. They are (in ascending order): (1) physiological; (2) safety; (3) belonging; (4) esteem; and (5) self-actualization. ${ }^{211}$ The premise of the theory is that a person will not seek to meet a higher level of need until the ones below it are met. For example, “[y]ou can't motivate someone to achieve their sales target (level 4) when they're having problems with their marriage (level 3)." 12 Additionally, "[y]ou can't expect someone to work as a team member (level 3) when they're having their house re-possessed (level 2). ${ }^{213}$

The Hierarchy has already found its way into the education arena in the special education context. ${ }^{214}$ But it can also be used as a blueprint for parents, teachers and community groups who are seeking education reform. The group seeking change can look to the Hierarchy to determine what needs, if any, are currently being met. The Hierarchy, of course, could be modified to meet the specific needs of an educational community. For example, the Hierarchy may begin with basic needs consisting of structurally sound schools, adequate books, and effective teaching techniques, and then move up to achieving culturally accurate standardized testing, and finally, balancing diversity and minority achievement at the university level. When used in conjunction with the holistic method (including all affected members of the community in decision-making) this approach may be just as, or even possibly more, effective than the litigation techniques described in the previous parts of this Note.

209. See infra Part III.B.iii.

210. Abraham H. Maslow, Motivation and Personality 35 (2d ed. 1970).

211. Id. at 35-47.

212. BusinessBalls.com, Maslow's Hierarchy of Needs, at http://www.businessballs.com/maslow.htm (last visited Jan. 9, 2004)

213. $I d$.

214. Norman Kune, The Need to Belong: Rediscovering Maslow's Hierarchy of Needs, in Restructuring for CARING And Effective Education, 25, 27-30 (Richard A. Villa et al. eds., 1992), available at http://www.normemma.com/armaslow.htm (last visited Jan. 9, 2004). 


\section{CONCLUSion}

As the possibility of the extinction of current affirmative action programs looms near, it is of utmost importance for the entire nation to reanalyze the current educational system. Achieving diversity at the university level is more important now than ever, but cannot be best achieved by temporary solutions applied at the admissions stage. Instead of dealing with the problem of poor education at the college level, legislators, judges, parents, teachers, and students should be examining more creative ways to prevent poor education in the first place. If the citizens of this country decide that diversity is important we must also be willing to provide educational opportunities for all children that, while unlikely to ever be equal, are at the very least not substandard and achieve some defined minimal level designed to prepare them for the future. Uneducated or undereducated children grow up to be uneducated or undereducated adults. The effects of illiteracy on this country cannot be ignored. "The Commerce Department estimates that the United States suffers a productivity loss of between $\$ 140$ billion and $\$ 300$ billion annually that is directly traceable to adult worker illiteracy." ${ }^{215}$ Furthermore, inadequate education may lead to increased health care $\operatorname{costs}^{216}$ and higher prison costs. ${ }^{217}$ But most importantly, inadequate education opportunities at the primary school level place unnecessary obstacles in the path of every child's future.

215. Quentin A. Palfrey, The State Judiciary's Role in Fulfilling Brown's Promise, 8 Mich. J. RACE \& L. 1, 39 (2002).

216. Id. at 39. Illiterate adults may have difficulty understanding health conditions, taking advantage of health care services and insurance programs, or taking medications. Id.

217. Id. at 39-40. 